\title{
Characterization of Egyptian Manganese Ores for Production of High Carbon Ferromanganese
}

\author{
Mohammed Salah Fahim', Hoda El Faramawy ${ }^{1}$, Azza Mohammed Ahmed ${ }^{1}$, \\ Saaed Nabil Ghali ${ }^{1}$, Abd El Hakim Taha Kandil ${ }^{2}$ \\ ${ }^{1}$ Department of Steel and Ferroalloys Technology, Central Metallurgical Research and Development Institute (CMRDI), \\ Cairo, Egypt. \\ ${ }^{2}$ Department of Chemistry, Faculty of Science, Helwan University, Cairo, Egypt \\ Email: mohammedsalah2020@gmail.com
}

Received January 23, 2012; revised February 25, 2013; accepted March 7, 2013

\begin{abstract}
This work aims at studying the reactivity of Egyptian manganese ores to be used in the production of ferromanganese alloys in submerged electric arc furnace. Ores with different manganese content (high-medium and low) were selected and characterized by X-Ray Fluorescence (XRF), X-Ray Diffraction (XRD) and Scanning Electron Microscope (SEM). The main mineralogical compositions in the three ores are pyrolusite $\left(\mathrm{MnO}_{2}\right)$ and hematite $\left(\mathrm{Fe}_{2} \mathrm{O}_{3}\right)$. Porosity of selected $\mathrm{Mn}$ ores was determined. The reactivity of the different ores was carried out through pre-reduction of the selected ores using thermobalance at $900^{\circ} \mathrm{C}$ and $1100^{\circ} \mathrm{C}$ and mixture of $\mathrm{CO}$ and $\mathrm{CO}_{2}$ gases. The reduction process was done until steady weight. The reduced ores were examined using XRD and SEM. The results showed that pyrolusite in high and medium ores are converted completely to $\mathrm{MnO}$ at $1100^{\circ} \mathrm{C}$. However, the ore with low manganese content was converted to $\mathrm{MnO}$ and $\mathrm{Mn}_{3} \mathrm{O}_{4}$. Consequently, it is clear from the results that $\mathrm{Mn}$ ores with high and medium $\mathrm{MnO}_{2}$ content are more reactive than those with low $\mathrm{MnO}_{2}$. Therefore, high $\mathrm{MnO}_{2}$ content $\mathrm{Mn}$ ores are preferable to get good economic impact during the production of high carbon ferromanganese.
\end{abstract}

Keywords: High Carbon Ferromanganese; Manganese Ores; Ore Reactivity; CO Reduction; Porosity

\section{Introduction}

Manganese is an essential alloying element in nearly all types of steel and is used to increase strength, toughness, hardness and hardenability. It is used for deoxidation and desulphurization of ferrous metals and alloys. Manganese is also important in the production of cast iron. Manganese is added to steel or cast iron in the form of manganese ferroalloys such as ferromanganese or silicomanganese alloys [1]. The rapid expansion in the world and Egyptian steel industry in recent years and consequently the increasing demand on the essential ferromanganese necessitated the domestic production of this ferroalloy.

Egyptian Manganese ores are located in Egypt in two major localities beside other several small occurrences. The economic deposits of manganese are Um Bogma in Central Western Sinai and Elba in South Eastern Desert. The reserve of these ores in Um Bogma is about 1.7 million tons. The only processing steps carried out on the manganese ores are crushing and screening [2].

Manganese oxides in manganese ores are reduced to manganese (ferromanganese) by carbon with heat supplied by carbon combustion in Blast Furnace (BF) and electric power in Submerged Electric Arc Furnaces (SAF)
[3]. Manganese ore reduction occurs in two stages in the first stage (pre-reduction), gaseous reduction of iron and manganese oxides to $\mathrm{FeO}$ and $\mathrm{MnO}$ by $\mathrm{CO}$ in the solid state. In the second stage, direct reduction of $\mathrm{MnO}, \mathrm{FeO}$ and $\mathrm{SiO}_{2}$ occurs by carbon producing work has been carried out a metallic $\mathrm{Mn}, \mathrm{Fe}$ and $\mathrm{Si}$. The completeness of the gaseous reduction, therefore, affects directly the economics of the production process through increasing the efficiency of carbonaceous reducer and decreasing the electric power consumption [1].

As the efficiency of these reactions affects the coke and the energy consumption, the ore reactivity can be considered as the most important parameter during production of ferromanganese [4,5].

There are three main parameters affecting on the manganese ore reactivity [6]:

1) The efficiency of the solid/gas exchange so that the higher the ore porosity the more complete reactions between higher manganese oxides and $\mathrm{CO}$ gas.

2) The available oxygen (Av Ox) which is the percentage of oxygen in ore bound to manganese above that associated with $\mathrm{MnO}$ and $\mathrm{FeO}$, i.e. the maximum quantity that could be released from reaction with $\mathrm{CO}$ 
gas. As the pre-reduction reactions being exothermic, the higher the available oxygen, the higher the energy will be released. This contributes to heat the burden in the pre-reduction zone and thus favors the reactions occurring in the second stage.

3) Particle size.

The pre-reduction process of manganese oxides in manganese ore i.e. gaseous reduction can occur according to the following equations [6-8]:

$$
\begin{aligned}
& \mathrm{MnO}_{2}+\mathrm{CO}(\mathrm{g})=\mathrm{MnO}+\mathrm{CO}_{2}(\mathrm{~g}) \\
& \mathrm{Mn}_{2} \mathrm{O}_{3}+\mathrm{CO}(\mathrm{g})=2 \mathrm{MnO}+\mathrm{CO}_{2}(\mathrm{~g}) \\
& \mathrm{Mn}_{3} \mathrm{O}_{4}+\mathrm{CO}(\mathrm{g})=3 \mathrm{MnO}+\mathrm{CO}_{2}(\mathrm{~g})
\end{aligned}
$$

Iron is always present in manganese ores, and the reduction of iron oxides present in manganese ores runs parallel to reduction of the higher manganese oxides. According to the equations:

$$
1 / 2 \mathrm{Fe}_{2} \mathrm{O}_{3}+3 / 2 \mathrm{CO}=\mathrm{Fe}+3 / 2 \mathrm{CO}
$$

However, the most possible reaction is the indirect reduction of higher iron oxides in the solid state by $\mathrm{CO}$ to FeO:

$$
\begin{aligned}
& \mathrm{Fe}_{2} \mathrm{O}_{3}+\mathrm{CO}=2 \mathrm{FeO}+\mathrm{CO}_{2} \\
& \mathrm{FeO}+\mathrm{CO}=\mathrm{Fe}+\mathrm{CO}_{2}
\end{aligned}
$$

This work aims at characterization of three grades of Egyptian manganese ores located in Um Bogma in Central Western Sinai, Egypt through studying the reactivity of these ores in the region of the gaseous reduction.

\section{Material and Methods}

Three grades of manganese ores with different chemical composition from Um Bogma mines were supplied by Sinai Manganese Company. These ores were crushed to small sizes $(<25 \mathrm{~mm})$. Representative samples of $\mathrm{Mn}$ ores for determination of chemical composition were analyzed by XRF method. Table 1 shows chemical composition of the representative samples of $\mathrm{Mn}$ ores.

\subsection{X-Ray Diffraction}

X-ray diffraction was done to determine the mineralogycal composition of the prepared samples at room temperature and diffraction patterns were obtained by means of a chart recording Philips PW (1790) X-ray diffracttometer using copper $(\mathrm{K} \alpha)$ radiation. The instrument was properly calibrated and adjusted with respect to the X-ray source. A high voltage of $40 \mathrm{kV}$ and a node current of 30 $\mathrm{mA}$ were chosen. The connected Geiger Muller tube detector was adjusted to the order of one degree/cm for

\begin{tabular}{|c|c|c|c|}
\hline Constituents & $\begin{array}{l}\text { Low Mn } \\
\text { Ore wt\% }\end{array}$ & $\begin{array}{c}\text { Medium } \\
\text { Mn Ore wt\% }\end{array}$ & $\begin{array}{l}\text { High Mn } \\
\text { Ore wt } \% \\
\end{array}$ \\
\hline $\mathrm{MnO}_{2}$ & 35.3 & 43 & 48.59 \\
\hline $\mathrm{Na}_{2} \mathrm{O}$ & 0.301 & 0.243 & 0.238 \\
\hline $\mathrm{MgO}$ & 1.571 & 1.521 & 0.864 \\
\hline $\mathrm{Al}_{2} \mathrm{O}_{3}$ & 0.958 & 2.097 & 1.03 \\
\hline $\mathrm{SiO}_{2}$ & 3.077 & 5.077 & 2.416 \\
\hline $\mathrm{P}_{2} \mathrm{O}_{5}$ & 0.168 & 0.33 & 0.277 \\
\hline $\mathrm{SO}_{3}$ & 0.715 & 0.73 & 0.525 \\
\hline $\mathrm{K}_{2} \mathrm{O}$ & 0.192 & 0.311 & 0.27 \\
\hline $\mathrm{CaO}$ & 3.02 & 2.279 & 2.249 \\
\hline $\mathrm{TiO}_{2}$ & 0.377 & 0.149 & 0.07 \\
\hline $\mathrm{Cr}_{2} \mathrm{O}_{3}$ & 0.053 & 0.056 & 0.058 \\
\hline $\mathrm{Fe}_{2} \mathrm{O}_{3}$ & 30.367 & 17.944 & 14.964 \\
\hline $\mathrm{Co}_{3} \mathrm{O}_{4}$ & 0.076 & 0.067 & 0.055 \\
\hline $\mathrm{NiO}$ & 0.046 & 0.047 & 0.061 \\
\hline $\mathrm{SrO}$ & 0.086 & 0.144 & 0.094 \\
\hline $\mathrm{CuO}$ & 0.102 & 0.112 & 0.224 \\
\hline $\mathrm{ZnO}$ & 0.64 & 0.387 & 0.465 \\
\hline $\mathrm{BaO}$ & 1.546 & 2.29 & 1.622 \\
\hline $\mathrm{PbO}$ & 0.052 & 0.063 & 0.041 \\
\hline $\mathrm{Cl}$ & 0.19 & 0.135 & 0.113 \\
\hline L.O.I & 11.7 & 11.8 & 12.4 \\
\hline $\mathrm{Mn} / \mathrm{Fe}_{\text {calculated }}$ & 1.46 & 3.315 & 4.54 \\
\hline Av. $O x_{\text {calculated }}$ & 9.53 & 9.7 & 10.44 \\
\hline
\end{tabular}
identification purposes.

\subsection{Scanning Electron Microscope}

JEOL, JSM-5410 Scanning Microscope was used to ex-
Table 1. Chemical composition of um bogma manganese ores.

amine the morphological structure of the ores before and after the reduction process. The sample to be examined was fixed into an epoxy resin mould, and then examined under JEOL, JSM-5410 Scanning Microscope.

\subsection{Density and Porosity}

Boiling water method was used to determine sealed pore, true and apparent porosity. Specific gravity bottle method (pycnometer) was used to determine true density for each ores.

\subsection{Reactivity Test}

The reactivity tests were carried out by gaseous reduction of manganese ores using $60 \% \mathrm{CO}-40 \% \mathrm{CO}_{2}$ gas mixture and the experiments were carried out at temperatures of $900^{\circ} \mathrm{C}$ and $1100^{\circ} \mathrm{C}$ in a vertical furnace. Nitrogen gas used for removing any gas found in the furnace at the beginning of the experiment and after the experiment also nitrogen gas pass through the furnace to remove $\mathrm{CO}$ and $\mathrm{CO}_{2}$ gasses as the sample must be introduced and taken from the furnace in the presence of nitrogen gas. 


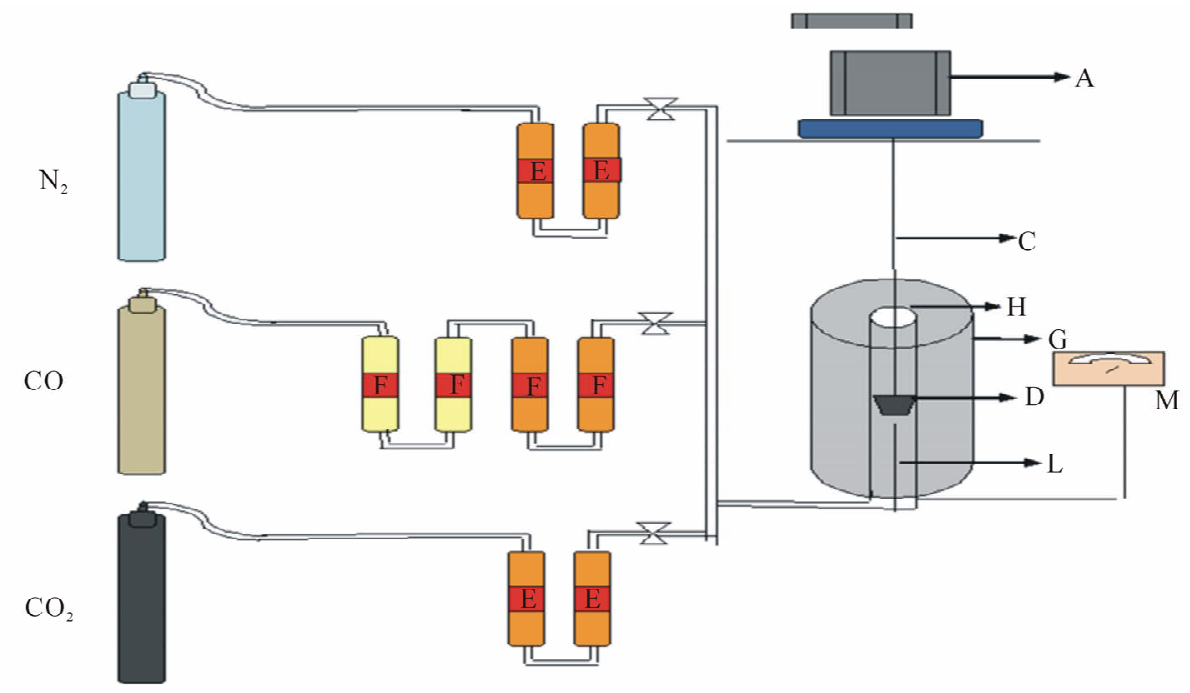

Figure 1. Schematic diagram of reactivity apparatus.

Reactivity of different Mn ores was measured using the system given in Figure 1. The system mainly consists of three parts. The first part is carbon monoxide, carbon dioxide and nitrogen gas cylinders. The second one is purification unit to purify the gases before their use (E) anhydrous silica gel towers and (F) soda lime granules towers. The third part is the thermo balance which consists of vertical tube furnace (G) wounded by a kanthal wire for attaining a maximum temperature of $1200^{\circ} \mathrm{C}$, a $\mathrm{Ni} / \mathrm{Ni}-\mathrm{Cr}$ thermocouple $(\mathrm{L})$ and the reaction tube $(\mathrm{H})$, which is a fused alumina tube. The samples were placed inside a kanthal wire basket (D) suspended by a kanthal wire (C) attached to the pan of a fully automatic sensitive $(0.1 \mathrm{mg})$ balance $(\mathrm{A})$.

The furnace was heated to the required reduction temperature. After reaching this temperature, oxygen free nitrogen gas was flushed into the furnace to remove any contaminants gas in the reaction tube by rate flow 1liter /min.

A kanthal wire basket (D) was placed in the furnace and was weighed as empty then taken from the furnace and was leaved to be cooled then the sample put in it and then the basket (D) with the sample were introduced into the furnace $(G)$ so as to be in the middle of its constant hot zone, in presence of nitrogen gas flushing, Then the mixture of $\mathrm{CO}$ and $\mathrm{CO}_{2}$ gases was flushed into the reaction tube by flow rate $600 \mathrm{ml} / \mathrm{min}$ and $400 \mathrm{ml} / \mathrm{min}$, respectively. The weight loss due to oxygen removal from the samples was intervally recorded with time until the weight of the sample becomes constant. At the end of the experiment, the basket and the sample were dropped into pure acetone to save the phases that formed in the reduced sample.

The reduction rate ( $\mathrm{R} \%)$ can be calculated by the following equation:

$$
\begin{aligned}
\mathrm{R} \% & =[\mathrm{wt} \text { at time }(0) \\
& -\mathrm{wt} \text { at time }(\mathrm{t})] / \text { available oxygen }(\mathrm{O} \%)
\end{aligned}
$$

The available oxygen calculated in this work as the excess or removable oxygen that can be reduced from pyrolusite to reach Manganosite and hematite to reach wustite according to the following equations:

$$
\begin{gathered}
\mathrm{MnO}_{2}=\mathrm{MnO}+1 / 2 \mathrm{O}_{2} \\
\mathrm{Fe}_{2} \mathrm{O}_{3}=2 \mathrm{FeO}+1 / 2 \mathrm{O}_{2}
\end{gathered}
$$

\section{Result and Discussion}

The chemical composition of the three selected manganese ores, given in Table 1, indicates that increasing the percentage of manganese in the manganese ore, the iron content decreases and consequently it's available oxygen for pre-reduction increases. However as the manganese in the high manganese ore highly oxidized, which could lead to an important exothermic effect in the pre-reduction zone of the furnace which will lead to lower electric power consumption.

The examination of the selected ores by XRD showed that, as it is clear from Figure 2, manganese oxide in the ores is mainly in the form of pyrolusite $\left(\mathrm{MnO}_{2}\right)$ and iron is present as hematite $\left(\mathrm{Fe}_{2} \mathrm{O}_{3}\right)$. It is also clear that with the decrease of the manganese content, the iron content increases.

The results of porosities determination for different ores are given in Table 2. It is clear from the results that the porosity of medium and low manganese ores is nearly similar. The results of measuring densities of ore size of $1 \mathrm{~mm}$ given in Table 2.

Photos of the three prepared samples of Mn ores examined by SEM are shown in Figure 3. It can be ob- 


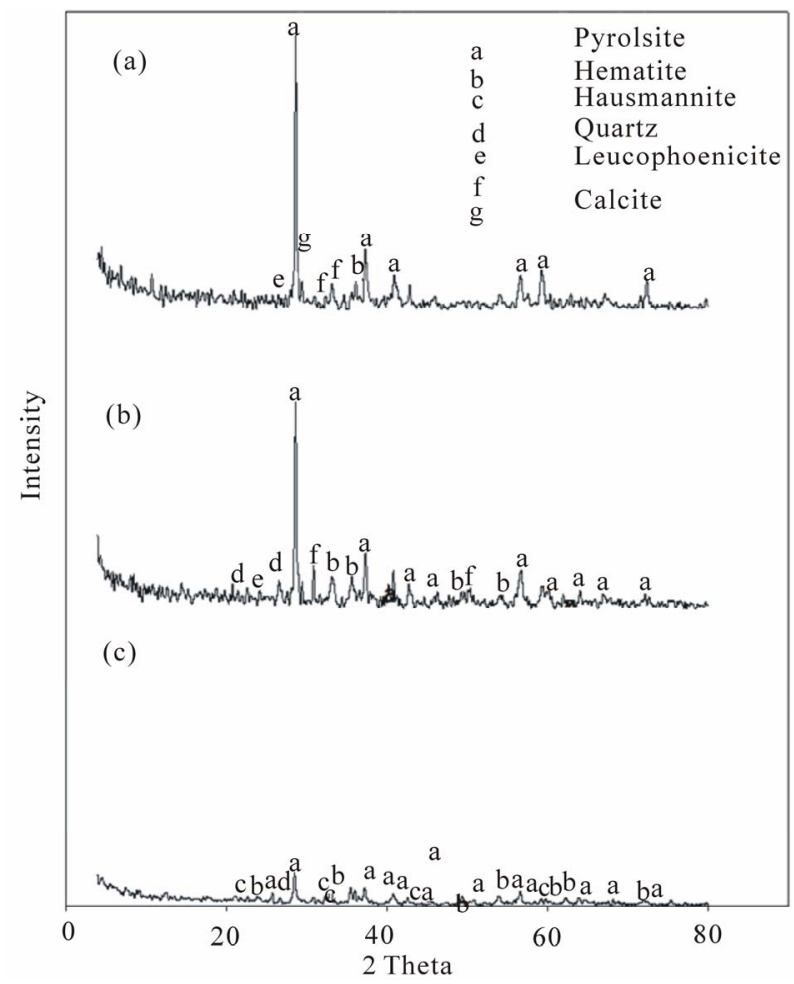

Figure 2. XRD of Mn ores: (a) High Mn ore; (b) Medium Mn ore; (c) Low Mn ore.

Table 2. True porosity, apparent porosity and sealed pores and true density of the three investigated Mn ores.

\begin{tabular}{ccccc}
\hline Material & \multicolumn{3}{c}{ Porosity \% } & density \\
\hline & Apparent & True & Sealed pores & true \\
\hline Low grade ore & 17.70 & 20.37 & 2.68 & 3.669 \\
Medium grade ore & 16.89 & 18.21 & 1.32 & 3.9027 \\
High grade ore & 35.89 & 36.17 & 0.28 & 3.94 \\
\hline
\end{tabular}

served from the examination of the different ores, that the ores particles are agglomerated forming dense grains.

The results obtained from the reduction experiments are represented in Figure 4.

Figure 4(a) indicates that the pre-reduction process of low, medium and high grade $\mathrm{Mn}$ ores at $900^{\circ} \mathrm{C}$ increases sharply with time at the first stages of reduction for the three ores, then the reduction rate tends to be steady at a certain time. The reduction rate for high grade ore is higher than medium and low grade ores. This may be attributed to the effect of available oxygen as the high grade ore have high available oxygen than the other two grades which significantly affects on the pre-reduction and reactivity. Figure 4(b) indicates that the pre-reduction process of low, medium and high grade Mn ores at $1100^{\circ} \mathrm{C}$ has the same behavior as at $900^{\circ} \mathrm{C}$. However, there are small increases in the reduction rate for the

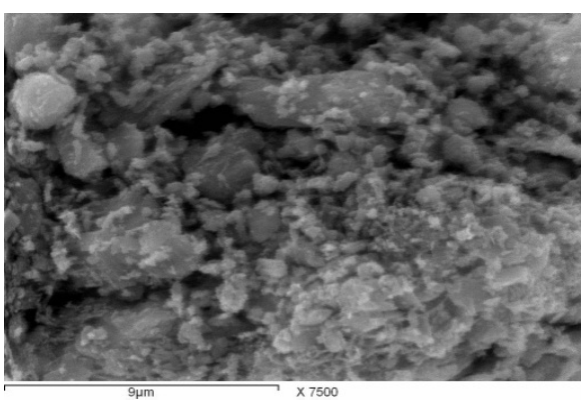

(a)

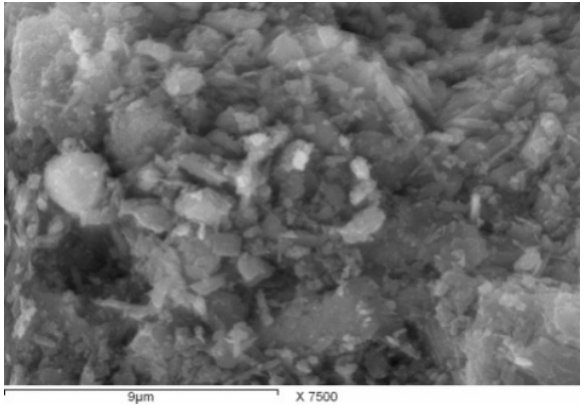

(b)

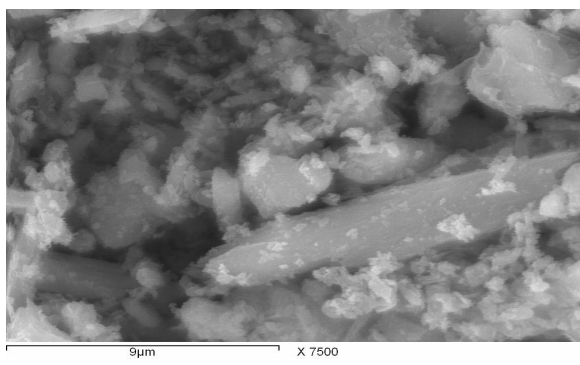

(c)

Figure 3. SEM for Manganese ores: (a) Low Mn ore; (b) Medium Mn ore; (c) High Mn ore.

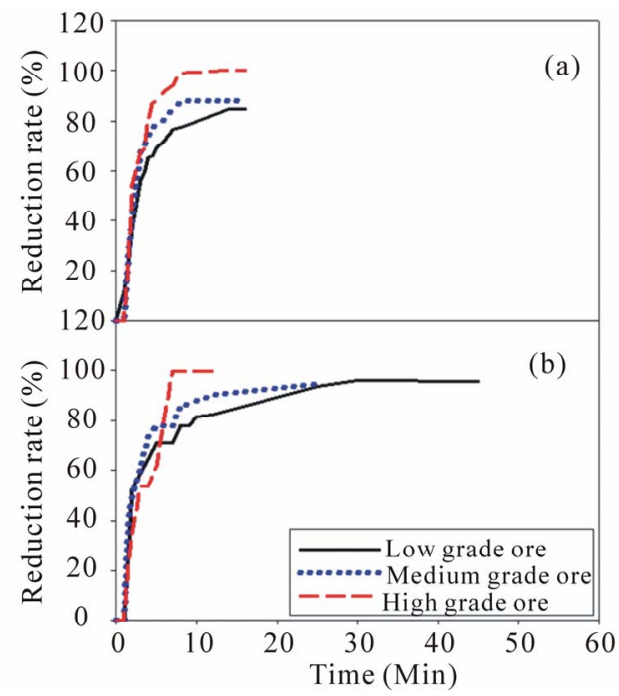

Figure 4. Reduction rate for low, medium and high grade manganese ore: (a) Reduction rate at $900^{\circ} \mathrm{C}$; (b) Reduction rate at $1100^{\circ} \mathrm{C}$. 
three manganese ores at $1100^{\circ} \mathrm{C}$ than the reduction rate at $900^{\circ} \mathrm{C}$ and this increase is more remarkable for the low grade ore than the other two ores. To explain the main differences between the pre-reduction at $900^{\circ} \mathrm{C}$ and $1100^{\circ} \mathrm{C} \mathrm{XRD} \mathrm{examination} \mathrm{was} \mathrm{done} \mathrm{for} \mathrm{the} \mathrm{samples} \mathrm{after}$ reduction.

The mineralogical composition determined using XRD

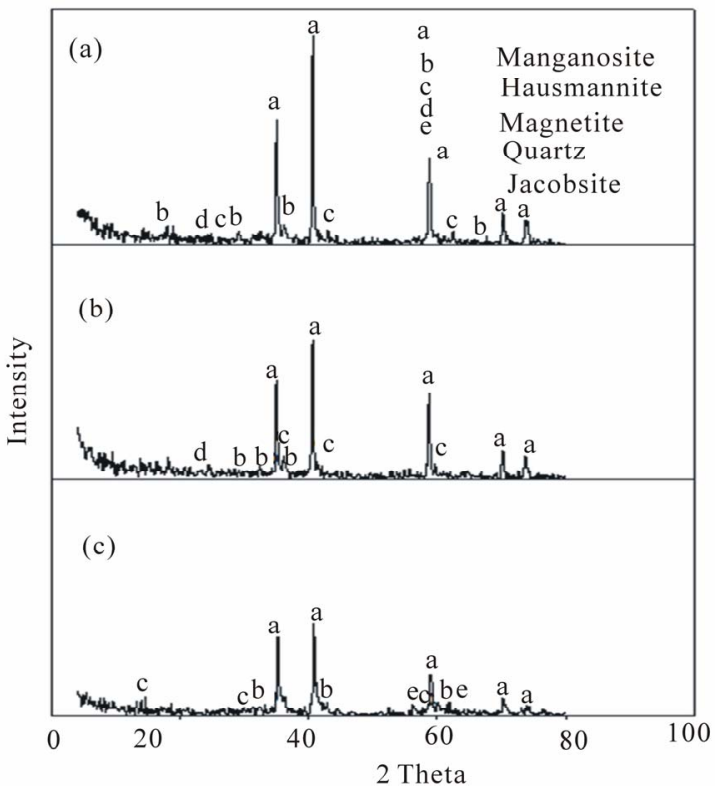

Figure 5. XRD of $\mathrm{Mn}$ ores after reduction tests at $900^{\circ} \mathrm{C}$ : (a) High Mn ore; (b) Medium Mn ore; (c) Low Mn ore.

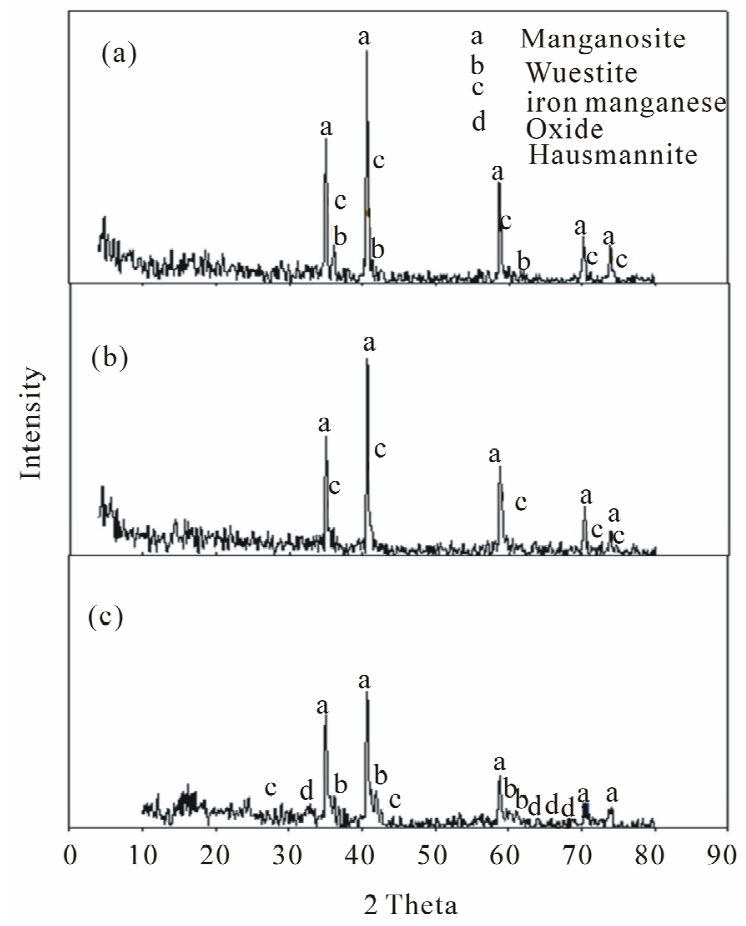

Figure 6. XRD of $\mathrm{Mn}$ ores after reduction tests at $1100^{\circ} \mathrm{C}$ : (a) High Mn ore; (b) Medium Mn ore; (c) Low Mn ore. of the reduced ores is indicated in Figures 5 and 6. These figures show that the highest reduction degree of Pyrolusite $\mathrm{MnO}_{2}$ to Manganosite $\mathrm{MnO}$ was achieved at $1100^{\circ} \mathrm{C}$.

Comparison of the mineralogical compositions of Low grade ore before and after the reduction can be indicated in Figures 2, 5 and 6 respectively.

It can be observed that after reduction test at $900^{\circ} \mathrm{C}$ Pyrolusite $\mathrm{MnO}_{2}$ is reduced to Hausmannite $\mathrm{Mn}_{3} \mathrm{O}_{4}$, and Hausmannite $\mathrm{Mn}_{3} \mathrm{O}_{4}$ is reduced to Manganosite $\mathrm{MnO}$. Hematite $\mathrm{Fe}_{2} \mathrm{O}_{3}$ is reduced to Magnetite $\mathrm{Fe}_{3} \mathrm{O}_{4}$. After reduction at $1100^{\circ} \mathrm{C}$ the mineralogical composition changed from magnetite $\mathrm{Fe}_{3} \mathrm{O}_{4}$ to Wustite $\mathrm{FeO}$, iron manganese oxide, and part of Hausmannite $\mathrm{Mn}_{3} \mathrm{O}_{4}$ to Manganosite $\mathrm{MnO}$.

When comparing between the mineralogical composition of medium grade ore before and after reduction test at $900^{\circ} \mathrm{C}$, it can be observed that Pyrolusite $\mathrm{MnO}_{2}$ is reduced to Hausmannite $\mathrm{Mn}_{3} \mathrm{O}_{4}$, Hausmannite $\mathrm{Mn}_{3} \mathrm{O}_{4}$ is reduced to Manganosite $\mathrm{MnO}$, and Hematite $\mathrm{Fe}_{2} \mathrm{O}_{3}$ is reduced to Magnetite $\mathrm{Fe}_{3} \mathrm{O}_{4}$. After reduction at $1100^{\circ} \mathrm{C}$ the mineralogical composition changed from $\mathrm{Fe}_{3} \mathrm{O}_{4}$ and Hausmannite $\mathrm{Mn}_{3} \mathrm{O}_{4}$ to iron manganese oxide and Manganosite.

When comparing between the mineralogical composition of high manganese ore before and after reduction test at $900^{\circ} \mathrm{C}$ it can be observed that Pyrolusite $\mathrm{MnO}_{2}$ is reduced to Hausmannite $\mathrm{Mn}_{3} \mathrm{O}_{4}$, Hausmannite $\mathrm{Mn}_{3} \mathrm{O}_{4}$ is reduced to Manganosite $\mathrm{MnO}$, Hematite $\mathrm{Fe}_{2} \mathrm{O}_{3}$ is reduced to Magnetite $\mathrm{Fe}_{3} \mathrm{O}_{4}$. After reduction at $1100^{\circ} \mathrm{C}$ the mineralogical composition changed from $\mathrm{Fe}_{3} \mathrm{O}_{4}$ and Hausmannite $\mathrm{Mn}_{3} \mathrm{O}_{4}$ to Wustite $\mathrm{FeO}$, iron manganese oxide and Manganosite.

By comparing the phases present after reduction at $900^{\circ} \mathrm{C}$ and $1100^{\circ} \mathrm{C}$. It can be observed that:

1) Most of hausmannite, $\mathrm{Mn}_{3} \mathrm{O}_{4}$ observed at $900^{\circ} \mathrm{C}$ turned into $\mathrm{MnO}$ at $1100^{\circ} \mathrm{C}$.

2) Magnetite, $\mathrm{Fe}_{2} \mathrm{O}_{3}$ appeared at $900^{\circ} \mathrm{C}$ turned into $\mathrm{FeO}$ at $1100^{\circ} \mathrm{C}$.

3) Iron manganese oxide phase complex formed at $1100^{\circ} \mathrm{C}$

The first and the second observation leads to increase in the reduction rate while the third one leads to decrease in the reduction rate [8]. It seems that the effect of the first and second observation is stronger than the third one, and this explains why the reduction rate increases by increasing temperature from $900^{\circ} \mathrm{C}$ to $1100^{\circ} \mathrm{C}$. At the same time, the formation of iron manganese oxides phase complex in the three ores retards the reduction process. The retardation is clearly noticeable in the low grade $\mathrm{Mn}$ ore due to the high percentage of iron oxide .It seems that this increase in iron oxides leads to increase of iron manganese oxide complex which is a hardly reducible 
one and its formation will lead to retardation of the reduction process. This is clear from the composition of the low grade ore after reduction which showed that the $\mathrm{Mn}_{3} \mathrm{O}_{4}$ did not converted to $\mathrm{MnO}$ while for the other two grade ores i.e. medium and high has been reduced to $\mathrm{MnO}$.

The reactivity of manganese ores in the pre-reduction is highly affected by the efficiency of the solid/gas exchange [9].

Thus, the higher the ore porosity the more complete reactions between higher manganese oxides and $\mathrm{CO}$ gas. A higher porosity leads to a high exchange surface with CO gas. The high reactivity of the ore with high manganese content can be due to its higher porosity compared with that containing lower content of manganese as seen in Table 2.

The morphological observations of reduced samples at $900^{\circ} \mathrm{C}$ and $1100^{\circ} \mathrm{C}$ reduction temperatures are shown in Figure 7. It can be seen that the reduced product at the higher temperature $1100^{\circ} \mathrm{C}$ is more homogenous. SEM analysis detected two phases in the ore matrix; the major light phase has higher manganese content, while the second dark phase has higher iron, silicon and aluminum.

From the preceding results of pre-reduction experiments and examination of the produced products by XRD and SEM, it is clear that the pre-reduction of $\mathrm{MnO}_{2}$ to $\mathrm{MnO}$ was happened which is in agreement with other works [6-8]. The highest reduction degree of $\mathrm{MnO}_{2}$ to $\mathrm{MnO}$ was achieved at $1100^{\circ} \mathrm{C}$ for high and medium $\mathrm{Mn}$ ore.

The advantage of operating with Egyptian high and medium manganese ores is that it will give low power consumption and thus a high tonnage for the same power input. The main reasons for this are first, the high oxygen content, and next, the good reactivity of these ores. As the reduction of the higher manganese oxides are all exothermic, when reduced with CO gas, higher oxygen content in the ore will lead to lower power consumption.

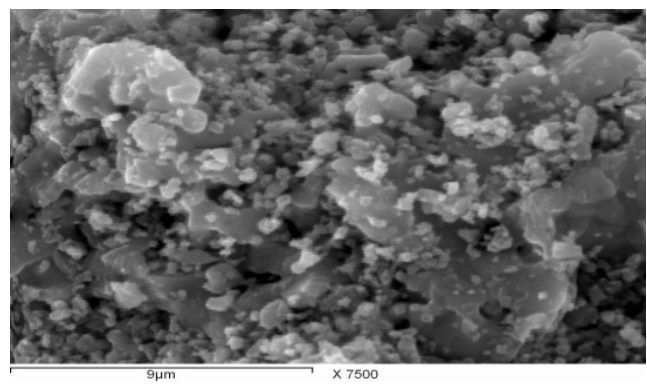

At $900^{\circ} \mathrm{C}$

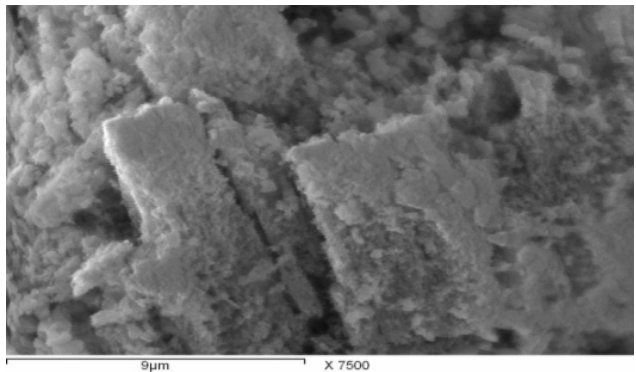

At $900^{\circ} \mathrm{C}$

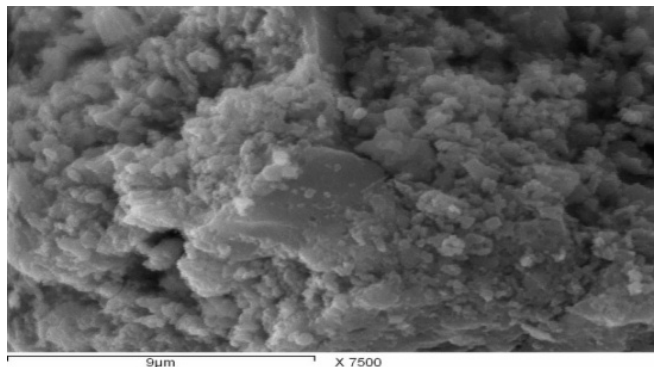

At $900^{\circ} \mathrm{C}$

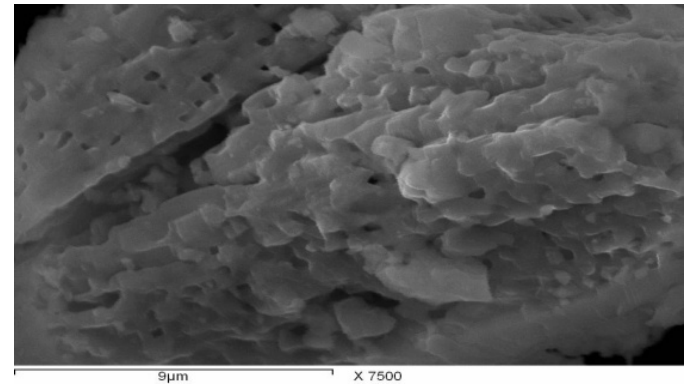

At $1100^{\circ} \mathrm{C}$

(a)

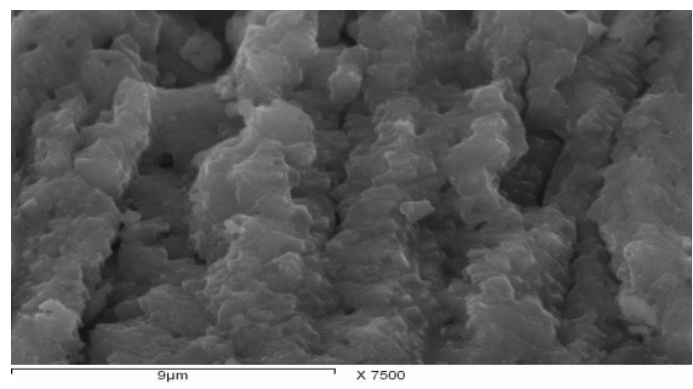

At $1100^{\circ} \mathrm{C}$

(b)

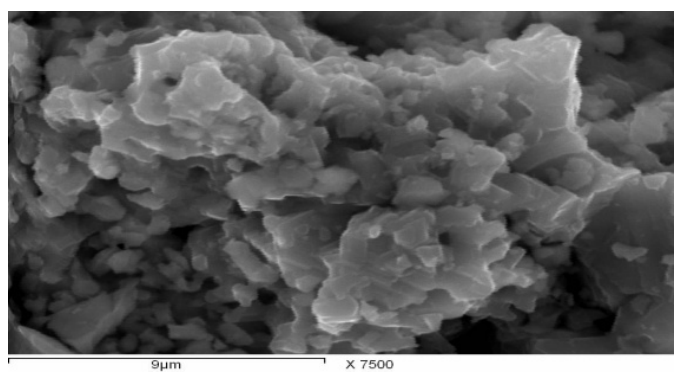

At $1100^{\circ} \mathrm{C}$

(c)

Figure 7. SEM for Manganese ores after reactivity test 900 and $1100^{\circ} \mathrm{C}$ : (a) Low Mn ore; (b) Medium Mn ore; (c) High Mn ore. 


\section{Conclusions}

From the obtained results it can be concluded that:

1) The Egyptian manganese ore of the three grades examined constituents mainly of pyrolusite $\mathrm{MnO}_{2}$ and Hematite $\mathrm{Fe}_{2} \mathrm{O}_{3}$, which refer to the high percent of removable oxygen which can save energy in the production of high carbon ferromanganese.

2) The porosity of high $\mathrm{Mn}$ ore is higher than low and medium Mn ores which increases the ability to use high and medium Mn ores for the production process of $\mathrm{HC}-\mathrm{Fe} \mathrm{Mn}$ as the increase of the ores porosity leads to increase of permeability and consequently sustainability for reduction.

3) The reduction rate for high $\mathrm{Mn}$ ore is more than medium $\mathrm{Mn}$ ore more than low $\mathrm{Mn}$ ore at $900^{\circ} \mathrm{C}$

4) Small increases in the reduction rate at $1100^{\circ} \mathrm{C}$ of the three manganese ore. But the increase in reduction rate of low grade manganese ores higher than the increases in the reduction rate for the medium and high grade manganese ore may be due to high percentage of iron oxide in the low grade ore.

5) The formation of iron manganese oxide phase complex in the three ores retards the pre-reduction process. But the effect of retardation is clearly noticeable in the low grade Mn ore due to high percentage of iron oxide which can be explained by the conversion of all pyrolusite to $\mathrm{MnO}$ at $1100^{\circ} \mathrm{C}$ in the medium and high grade but in the low grade pyrolusite converted to $\mathrm{Mn}_{3} \mathrm{O}_{4}$ due to the higher percent of $\mathrm{Fe}$ in the low grade than in the other two grade ores.

\section{REFERENCES}

[1] G. Pochart, L. Joncourt, N. Touchard and C. Perdon, "Metallurgical Benefit Of Reactive High Grade Ore in
Manganese Alloys Manufacturing,” INFACON XI, 2007, pp. 217-230.

[2] A.-Z. M. Abouzeid1 and A.-A. M. Khalid, "Mineral Industry in Egypt-Part I: Metallic Mineral Commodities," Natural Resources, Vol. 2, No. 1, 2011, pp. 35-53. doi:10.4236/nr.2011.21006

[3] E. C. Vanderstaay, D. R. Swinbourne and M. Monteiro, "A Computational Thermodynamics Model of Submerged Arc Electric Furnace Ferromanganese Smelting," Mineral Processing and Extractive Metallurgy, Vol. 113, No. 1, 2004, pp. 38-44. doi:10.1179/037195504225004706

[4] M. Tangstad, S. Wasb and R. Tronstad, "Kinetics of the Pre-reduction of Manganese Ores,” INFACON 9, Quebec City, 2001

[5] M. Tangstad and S. Olsen, "The Ferromanganese Process -Material and Energy Balance,” INFACON 7, Trondheim, 1995, pp. 621-630.

[6] M. Tangstad P. Calvert, H. Brun1 and A. G. Lindseth, "Use of Comilog Ore in Ferromanganese Production," Proceedings of Tenth International Ferroalloys Congress, Cape Town, 1-4 February 2004, pp. 213-222.

[7] K. L. Berg, "Gaseous Reduction of Manganese Ores," Ph.D. Thesis, Faculty of Information Technology, Mathematics and Electrical Engineering, The Norwegian University of Science and Technology, Trondheim, 1998, p. 72.

[8] A. A. El-Geassy, M. I. Nasr, A. A. Omar and E. A. Mousa, "Isothermal Reduction Behavior of $\mathrm{MnO}_{2}$ Doped $\mathrm{Fe}_{2} \mathrm{O}_{3}$ Compacts with $\mathrm{H}_{2}$ at 1073 - $1373 \mathrm{~K}$," Ironmaking and Steelmaking, Vol. 35, No. 7, 2008 pp. 531-538. doi:10.1179/174328108X58532

[9] R. Ishak and M. Tangstad, "Degree of Prereduction without Coke Consumption in Industrial Furnaces,” INFACON XI, 2007, pp. 268-279. 